\title{
ШАХТЕРСКАЯ ТЕМА В ЖУРНАЛЬНОЙ ГРАФИКЕ АЛЕКСАНДРА ДЕЙНЕКИ СЕРЕДИНЫ 1920-х ГГ. (ЖУРНАЛ «У СТАНКА»)
}

\section{MINER'S THEME IN ALEXANDER DEINEKA'S MAGAZINE GRAPHICS OF THE MID-1920s ( THE MAGAZINE «AT THE BENCH»)}

\author{
Е.П. Максименко \\ E.P. Maksimenko \\ Национальный исследовательский технологический университет «МИСиС», \\ Россия, 119049, г. Москва, Ленинский проспект, д. 4 \\ NUST «MISIS», \\ 4 Leninskij prospekt, Moscow, 119049, Russia \\ E-Mail: maksimenko.ep@misis.ru
}

\begin{abstract}
Аннотация
В статье в качестве визуального источника исторической информации о шахтерском Донбассе периода нэпа рассмотрены графические рисунки Александра Дейнеки, опубликованные в середине 1920-х гг. в журнале «У станка». Впервые предпринята попытка анализа графической серии «В Донбассе» не как художественного цикла, отражающего творческий поиск автора, а как иллюстративного материала, рассказывающего о шахтерских рабочих буднях и актуальных вопросах, связанных с процессом восстановления угольного региона и с нарастающими темпами его индустриального развития. Методология исследования основана на анализе сюжетного содержания данных визуальных источников в контексте некоторых вопросов промышленного, социального, культурного развития шахтерского региона в середине 1920-х гг.
\end{abstract}

\begin{abstract}
The article discusses the pictures made by Alexander Deineka and published in the magazine «At the bench» in the mid-1920s as a visual source of historical information about the miner's Donbass period of the NEP. Close attention to the contemporary events allowed the artist to use a method of observation inaccessible to historians, expanding the possibilities of studying that historical period. The author of the article for the first time made an attempt to analyze the graphic series «In the Donbass» not as an art cycle reflecting the artist's creative search, but as an illustrative material telling about mining workdays and important issues related to the process of restoration of the coal region and the increasing pace of its industrial development. The research methodology is based on the analysis of the plot content of these visual sources in the context of certain issues of industrial, social, and cultural development of the mining region in the mid-1920s.
\end{abstract}

Ключевые слова: промышленная тема, журнальная графика, Донбасс, нэп, угольная промышленность, шахтеры-угольщики, периодическая печать, ликвидация безграмотности, ручной труд, механизация, кадровый потенциал.

Keywords: industrial theme, magazine graphics, Donbass, NEP, coal industry, coal miners, periodicals, elimination of illiteracy, manual labor, mechanization, staff potential.

Выдающийся советский художник Александр Александрович Дейнека к шахтерской тематике обращался неоднократно - в многочисленных набросках, в графических и живописных работах разных лет. По собственному признанию мастера, ему «пришлось работать в самых разнообразных видах и техниках художественного творчества». Подобную многоликость творческой деятельности Дейнека связывал не только со свойством 
собственного характера, но считал особенностью времени, в котором жил: «Возникают новые задачи у страны, выдвигаются новые изобразительные формы» [Дейнека, 1961].

В молодые годы убежденность в необходимости слияния задач художественного творчества с задачами социального строительства привело Дейнеку в знаковое учебное заведение - Московские высшие государственные художественно-технические мастерские, более известные как ВХУТЕМАС. В постановлении СНК РСФСР от 18 декабря 1920 г. об открытии нового учебного заведения его цель была сформулирована вполне определенно: «...подготовить художников - мастеров высшей квалификации для промышленности» [Постановление СНК...].

Структурной спецификой мастерских было объединение факультетов разной направленности. К творческим факультетам относились живописный, скульптурный и архитектурный, к производственным - печатно-графический, металлообрабатывающий, деревообделочный, текстильный и керамический. Большинство студентов обучались на архитектурном, живописном и графическом факультетах. На всех курсах обязательным являлось «преподавание политической грамоты и основ коммунистического мировоззрения». Таким образом, для творческой молодежи, принявшей революционные преобразования, открывалась заманчивая перспектива отобразить современность в ее послеоктябрьской специфике, в новом темпе жизни, в новых производственных реалиях.

Александр Дейнека поступил на графический факультет ВХУТЕМАС в 1921 г. К этому моменту фактами биографии 22-летнего уроженца Курска уже были работа инструктором Наробраза, работа в курском отделении «Окон РОСТА», работа фотографом в уголовном розыске, а также служба в Красной армии. Обучение в мастерских было рассчитано на четыре года, но в 1924 г., не дождавшись защиты дипломной работы, Дейнека уходит из ВХУТЕМАС, поскольку администрация не засчитала ему летнюю практику, проведенную в качестве художника-иллюстратора журнала «Безбожник у станка» [Сысоев, 1989, с. 18].

Молодому полиграфисту хотелось скорее заняться реальным, конкретным делом. В то время иллюстрированные журналы имели огромное общественное и художественное значение. В Москве 1920-х гг. происходил настоящий журнальный бум. Поскольку для советской полиграфии той поры технология непосредственного воспроизведения фотографий в массовых изданиях представляла определенные трудности, редакции были заинтересованы в труде художников, обеспечивавших большинство журналов превосходными рисунками. Специфика периодических изданий ставила перед художникамиграфиками одновременно творческие и социально-значимые задачи. Редакциями ценилась их способность немедленно откликаться на волнующие события дня, отбирать самое типичное, обобщать явления, создавать образ, характер, передавать идею посредством использования символов. Часто создаваемые ими графические изображения несли в себе упрощение формы изображаемого объекта, поскольку простые, понятные формы облегчали художникам работу и сильно сокращали время производственного цикла.

Агитационные журналы «Безбожник у станка» и «У станка», куда Дейнеку приняли в штат, издавались Московским комитетом РКП(б) и печатались многотысячными тиражами. Они собрали первоклассный художественный коллектив - достаточно сказать, что всей художественной частью руководил Дмитрий Моор. Рисунки Дейнеки появлялись в них регулярно, иногда по несколько раз в одном номере.

Насыщенная журнальная практика позволила молодому художнику, определенно не расположенному писать «пейзан в лапоточках, французские пейзажи, дам в кринолинах», увидеть мир реальных вещей и событий, питавший его лучшие произведения середины 1920-х гг. [Дейнека, 1961]. «Я понял, что без знания жизни, без того, что толкает тебя на создание произведения, работать невозможно», - запишет Дейнека позднее. В период нэпа популярным становится изобразительное творчество, предполагавшее целенаправленное развитие идеологически значимой для нового государства промышленной темы.

Уже в апреле 1920 г., как только закончился самый тяжелый этап военного противостояния внутри страны, на I Всероссийском учредительном съезде горнорабочих 
В.И. Ленин назвал уголь настоящим хлебом промышленности. Причем задачу обеспечения промышленности углем советский лидер рассматривал как фактор даже более важный, чем победу на фронте: «чтобы спасти Советскую власть сейчас, необходимо дать хлеб для промышленности, т. е. уголь. Без этого нельзя восстановить хозяйство, нельзя пустить железные дороги, без этого нельзя пустить фабрики и дать предметы для обмена на хлеб крестьянам» [Ленин, 1974, с. 298].

Основные надежды государство возлагало на Донецкий угольный бассейн. Но его состояние после хаоса революционных лет, после разрухи, вызванной Первой мировой и Гражданской войнами, было ужасающим. Исследователь И.К. Сапицкая приводит данные комиссии проф. Б.И. Бокия, обследовавшей Донбасс летом 1920 г. Комиссия установила, что $39 \%$ всех эксплуатационных шахт были остановлены. Не работали 623 шахты из 1604 по следующим причинам: 256 (41\%) были затоплены; остановлено из-за отсутствия рабочих 180 (29\%) шахт; остальные $30 \%$ были остановлены по разным причинам [Сапицкая, 2009, с. 48].

С 1922 г. в советской России начался подъем экономики, а добыча угля восстанавливалась медленно. Если в 1913 г. промышленность потребляла 67,1 \% угля и 32,9 \% прочего топлива, главным образом дров, то в 1923-1924 гг. потребление угля в промышленности составляло всего 42 \% по отношению ко всему количеству потребленного топлива [Развитие советской экономики, 1940, с. 198]. Ситуация в промышленности в целом и в угольной отрасли в частности регулярно освещалась в советской периодической печати.

Задолго до того, как в практику широко вошли командировки художников на производство, Дейнека по заданиям редакций ездил в промышленные районы, где на месте изучал жизнь страны в годы восстановительного периода. Потом он напишет: «...в ту пору я ездил больше, чем когда-либо: я работал в шахтах Донбасса, был в подмосковных шахтах, ездил по колхозам и видел, как они создаются, работал на московских фабриках и заводах».

В середине 1920-х гг. журнал неоднократно командировал Дейнеку на Донбасс. Донецкий бассейн оставался основной угледобывающей базой страны, поэтому там шли процессы интенсивного промышленного восстановления и перевооружения. Всесоюзная кочегарка обеспечивала богатый натурный материал Дейнеке как художнику промышленности. Большое производство развернуло перед ним внушительный индустриальный пейзаж: шахтные копры, подъемные машины, надшахтные здания, сортировки и эстакады. Заходя в шахтные ламповые, нарядные, табельные, он получил возможность увидеть организацию внутреннего трудового распорядка на предприятиях. Вместе с рабочими клеть спускала молодого художника глубоко под землю, туда, где находилась главная часть этого особого шахтерского мира. Мимо бесконечных рядов из стоек крепи он вместе со всеми по штрекам шел к угольной лаве, чтобы в забое увидеть воочию то самое «торжественно-напряженное состояние труда», которое затем так стремился передать в своих произведениях.

Знакомясь с рабочим бытом рудников, Дейнека быстро фиксировал свои наблюдения. Он выполнил множество набросков рабочих на производстве: шахтер в кепке, облокотившийся локтем на перила (рис. 1a); шахтер со скрещенными на груди руками, что-то сосредоточенно обдумывающий (рис. 1б); шахтер, с усилием тянущий тяжелую угольную вагонетку (рис. 1в) и пр. Карандашные рисунки множили кипы набросков, из которых Дейнека затем выбирал, с его точки зрения, «самое типичное, образное» для создания лаконичной, полной естественной простоты и гармонии графической серии «В Донбассе».

На страницах журнала «У станка» Дейнекой представлены графические рисунки, зафиксировавшие реалии шахтерского бытия. Они выступают полноправным источником исторической информации о трудовой жизни шахтерского Донбасса. Повседневный путь его героев проходил через нарядную, ламповую и табельную. С табельной на угольных предприятиях связан ведущийся издавна обязательный подсчет всех спустившихся в шахту и вышедших (выехавших) из нее. Он необходим для получения оперативной информации о количестве работников, находящихся в каждый конкретный момент времени под землей, - во-первых, на случай аварийной ситуации, чтобы все были выведены в безопас- 
ное место, во-вторых, таким образом легко подсчитать фактически отработанное каждым угольщиком время. Поэтому в табельной горняки всякий раз обязательно получали два жетона («номерка») - «Спуск» и «Выезд» - со своими личными табельными номерами.

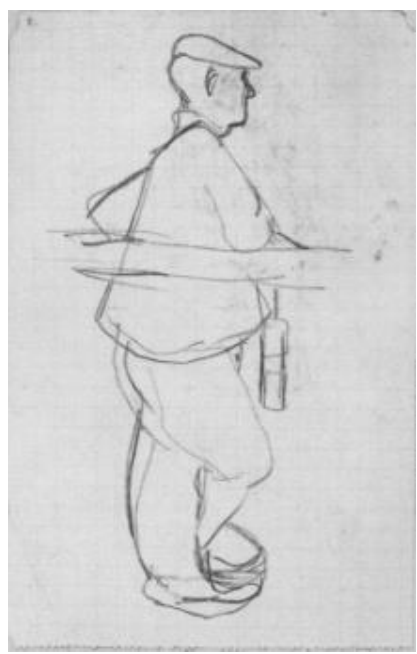

a)

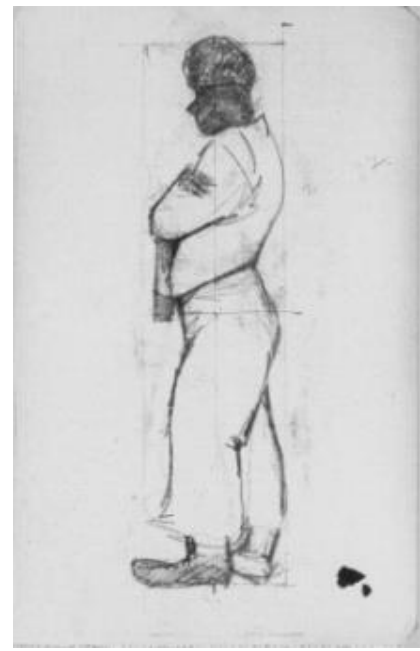

б)

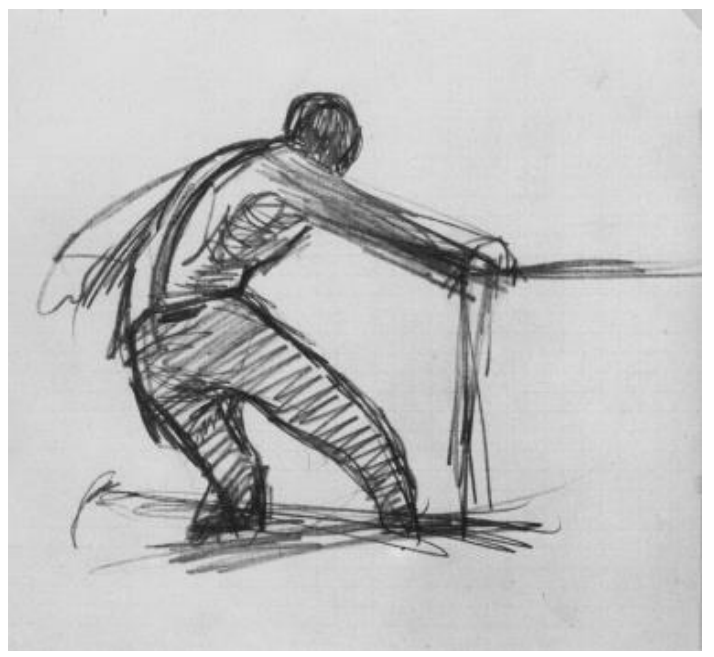

в)

Рис. 1. Шахтеры

Fig. 1. Coal miners

Здесь Дейнека и увидел персонажей рисунка под названием «Донбасс. У табельной» (рис. 2). Пространство рисунка почти полностью заполняют три коренастые фигуры рабочих-угольщиков; этот прием помогает художнику полностью сосредоточить внимание читателя на героях графической композиции.

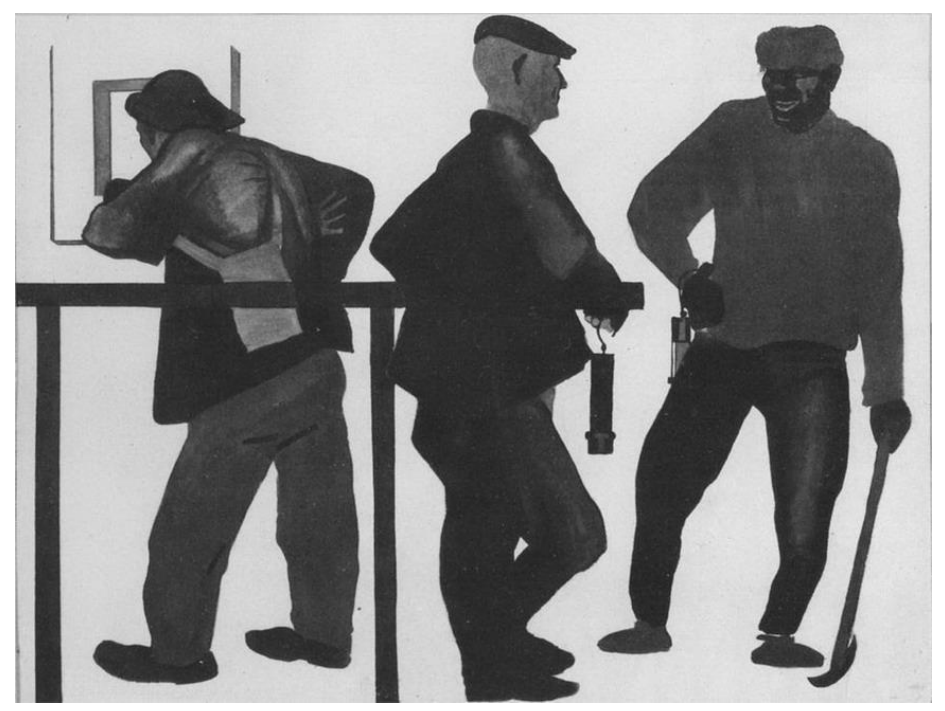

Рис. 2. Донбасс. У табельной

Fig. 2. Donbass. At the timecard room

Ведущий исследователь творчества Дейнеки В.П. Сысоев в свое время отметил, что художник умел «сообщить действию характер текучего формирующегося процесса, увлекающего воображение зрителя на путь самостоятельного домысливания выраженного содержания» [Сысоев, 1989, с. 42]. В тот момент, когда один из шахтеров склонился к небольшому оконцу табельщика, двое других ведут о чем-то разговор. В среднем персонаже сразу узнается человек с наброска (см. рис. 1a). Он облокотился рукой о перила и перенес вес тела на левую ногу, правую же слегка согнул в колене. Вполне возможно, что таким образом шахтер пытается облегчить боль в колене, спровоцированную постоянной рабо- 
той в неудобной позе и большим физическим напряжением. Второй из разговаривающих, тот, что повернулся лицом к зрителю, одной рукой упирается в бедро. Руки на бедрах первый признак готовности к активным действиям, о чем косвенно напоминает и обушок в другой руке, который забойщик тоже использует в качестве своеобразной опоры.

В иллюстрациях донбасского цикла расчет автора на способность читателя «додумать» обстановку, конкретизировать ее с помощью собственных представлений о действительности совершенно очевиден. Кроме «читаемых» поз Дейнека наделяет своих героев «читаемым» выражением лиц (при отсутствии индивидуализации черт), которое говорит об их позитивном настрое перед сменой. Собираясь на работу, связанную с ежеминутным риском обвала или осыпания горной породы, возможности взрыва метана и пр., шахтеры спокойно беседуют. Похоже, что рабочий с обушком рассказывает очередную шахтерскую байку или сообщает заинтересовавшую его новость.

Именно тему текущих новостей предполагает рисунок «Донбасс. За газетой» (рис. 3). Несколько человек стоят в очереди за свежими газетами, которые бойко расходятся прямо из окна административного здания. Обращение Дейнеки к подобному сюжету напрямую связано с проблемами культурного развития, в частности вопросами распространения периодической печати в регионе и уровня грамотности рабочего класса.

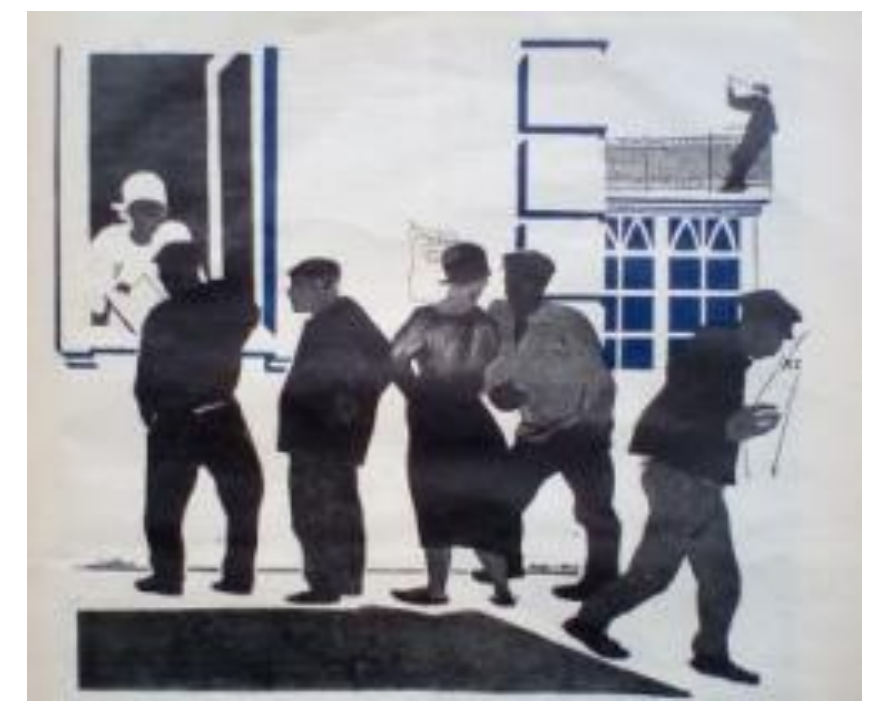

Рис. 3. За газетой

Fig. 3. For the newspaper

История прессы Донбасса началась на рубеже XIX и XX столетий, когда в Бахмуте и Мариуполе стали выходить первые газеты, носившие, как правило, информационнорекламный характер. Журналистики в чистом ее виде было очень мало. В основном публиковались заметки на житейские или криминальные темы, то есть то, что интересовало обывателя. Серьезная журналистика появилась значительно позже. Этому способствовала Первая мировая война, а потом - революция [Газетный пласт...]. Революция вызвала настоящий всплеск местных общественно-политических изданий, среди которых были «Всероссийская кочегарка» (1920, Бахмут), «Диктатура труда» (1920, Юзовка), «Молодой Донбасс» (1919, Юзовка) и др. Советская власть придавала важное значение газетам как инструменту, влияющему на «степень общественного развития» такой значимой социальной группы, как шахтеры: «Шахтер Донбасса нас интересует не только как источник рабочей силы, но и как общественный индивидуум, реагирующий на все явления общественной жизни» [Никольский, 2017, с. 14]. Но на пути формирования человека с новым сознанием стояла проблема элементарной безграмотности.

В декабре 1922 г. - январе 1923 г. Донецкий губернский совет профсоюзов провел письменное анкетирование горняков, входящих во Всероссийский союз горнорабочих. 
Опрос охватил 83787 чел. (всего по состоянию на 1 января 1923 г. в угольной промышленности Донбасса было занято около 122 тыс. чел.). По данным, введенным в научный оборот д. и. н. В.Н. Никольским, среди опрошенных не умели читать и писать каждый четвертый из шахтеров $(24,9 \%)$ и примерно столько же относили себя к категории малограмотных (24,2 \%). Не внушала оптимизма и статистика, отражавшая ситуацию с потреблением продукции периодической печати. Она показала, что «более двух третей опрошенных (55 914 чел.) газеты не читали; 14,8 \% (12 396 чел.) читали 1-5 газет; 4,9 \% (4 141 чел.) заявили, что читали 6-10 газет, а 10,6\% (8 862 чел.) - более 10 газет в месяц, 2474 чел. (2,9 \%) затруднились дать какой-либо ответ» [Никольский, 2017, с. 14].

Ликвидация неграмотности среди населения становилась одной из глобальных задач власти периода 1920-х гг., когда грамотность провозгласили одним из ключевых аспектов в развитии культурно-образовательной сферы. Уже по данным переписи 1926 г., хотя кампания была далека до своего завершающего этапа, среди промышленных рабочих в Донбассе неграмотными оставались 15 \% [История рабочих Донбасса, 1981, с. 262].

Наделенный острым ощущением духа времени, Дейнека понимал важность реконструкции сознания шахтерской рабочей массы. Он не прошел мимо идеологически значимого сюжета, связанного с актуальностью газет, их возможностью поднимать важные, злободневные вопросы и проблемы, их широкой доступностью и направленностью на освещение широкого спектра тем, интересующих читателей. Дейнека приехал в Донбасс запечатлевать реалии нового времени. Выступая очевидцем происходящего, график создавал своеобразный художественный репортаж с места событий, а детали, подмеченные им в результате личных наблюдений, помогали перенести туда воображение читателя. Мужчина расплачивается за газету. Молодой шахтер, пользуясь моментом, завел разговор со стоящей впереди него женщиной (именно эта возможность, скорее всего, и привела его в очередь за газетой). Рабочий, более старший по возрасту, начал просматривать свежий номер, едва отойдя от импровизированного газетного прилавка и пр. Своей ориентированностью на изображение достоверности момента художник делает рисунок похожим на документальный кинокадр.

С 1921 г. Высшим советом народного хозяйства выпускался ежегодник «Промышленность СССР» (по 1923 г. включительно назывался «Русская промышленность»), подготовкой которого занимался Центральный отдел статистики (ЦОС ВСНХ). Ежегодник состоял из двух частей. Первая посвящалась общим условиям работы промышленности: ее финансовому положению, кадровому обеспечению, топливоснабжению, ценам и себестоимости промышленных изделий, деятельности трестов и пр. Вторая содержала обзоры отдельных отраслей промышленности и неизменно начиналась с обзора каменноугольной промышленности. Кратким популяризированным журнальным вариантом этой части серьезного статистического издания было экономическое обозрение Владимира Сарабьянова «Наш Донбасс», напечатанное в журнале «У станка» [Сарабьянов, 1924]. Именно к этому тексту привлекала дополнительное внимание читателя эстетическая ценность рисунков Дейнеки. Сарабьянов в то время работал экономистом-обозревателем в газете «Правда», а также преподавал в московских вузах, в частности, в 1924-1925 гг. в Московской горной академии читал курс «Экономика и экономическая политика СССР». Материалу Сарабьянова, проиллюстрированному рисунками Дейнеки, в журнале отведен полный разворот. Экономический обзор начинается с констатации успехов в восстановлении каменноугольной промышленности страны после окончания гражданской войны. Автор сразу отмечает главную роль Донбасса в процессе минерализации топливного потребления, а затем останавливается на основных задачах отрасли: поднять качество добываемого угля и устранить перебои в его добыче; удешевить себестоимость угля; решить вопрос кадрового обеспечения отрасли.

Долгое время в угольной отрасли оставался актуальным вопрос механизации трудоемких процессов. Уровень механизации Донбасса - основного топливодобывающего района страны - продолжал оставаться крайне низким, здесь по-прежнему преобладал ручной труд. Механизация производственного процесса ограничивалась главным образом переходом от паровых двигателей к двигателям электромеханическим и заменой ручного 
способа добычи угля добычей с помощью врубовых машин. По данным упомянутого выше ежегодника ВCHX, в 1924-1925 хозяйственном году с применением врубовых машин на Донбассе было добыто 505 тыс. тонн угля, что составило всего 5,5 \% от общей добычи [Промышленность СССР..., 1926, с. 17].

На следующем рисунке Дейнеки четверо рабочих - трое мужчин и женщина (среди донбасских рабочих-горняков в тот период женщин было около $11 \%$ ) - заняты ручной погрузкой угля на железнодорожную платформу (рис. 4). Их фигуры изображены в свойственных манере Дейнеки выразительных ракурсах. От рисунка веет энергичным, волевым настроем его героев, занятых нелегким ручным трудом. Их жизнь основана на простой истине - «работать, строить и не ныть» (этот слоган появится затем на очень известном плакате Дейнеки 1930-х гг.). Энтузиазм, который рабочие вкладывают даже в неквалифицированный труд, придает действу масштабную жизненную проблематику.

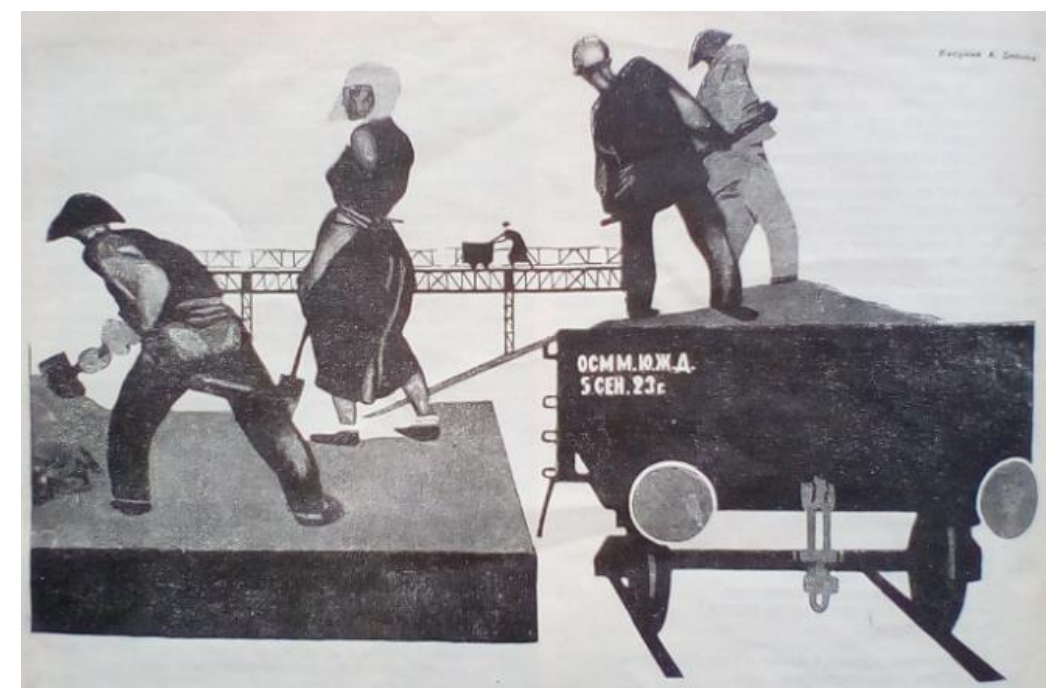

Рис. 4. Без названия

Fig. 4. No a title

Дейнека принципиально отказывался, подобно другим художникампроизводственникам, «пересказывать» в своих произведениях ежедневные будни промышленности. Обладая особым типом художественного мировосприятия, в котором преобладало «чувство будущего», он возвышал повседневность, ваял памятник труду на плоскости листа.

Художник проводил строгий отбор всех деталей изображения, что позволяло ему предельно лаконично и выразительно представить задуманный образ. Он, по словам искусствоведа Б.М. Никифорова, быстро подметил, что «условия производства накладывают яркий отпечаток на человека, на ритмику его движений, порождают своеобразие позы и черт характера» [Никифоров, 1937, с. 32], и вот уже читатель видит двоих шахтеров, устало возвращающихся домой после смены (рис. 5). Они идут медленной, тяжелой походкой, чуть ссутулившись и втянув голову в плечи. Эта привычка развивалась у рабочих рудников из-за необходимости постоянно беречь голову. Так необходимая шахтеру каска в массовый обиход вошла только в 1930-е гг. Кепки и картузы защищали от летящих сверху небольших кусков породы, но от случайных ощутимых ударов (например, о балку верхняка) не могли. Вот и приходилось угольщикам постоянно пригибаться.

На подчеркнуто «антиживописное» изображение рабочего человека, свойственное раннему периоду творчества Дейнеки, неоднократно обращали внимание искусствоведы.

«Его фигуры рабочих и работниц, неуклюжих, с выпирающими из одежды налитыми, крепко развитыми мускулами, полны в то же время какой-то особой неумелой грации и силы» [Рогинская, 1926, с. 232]. 


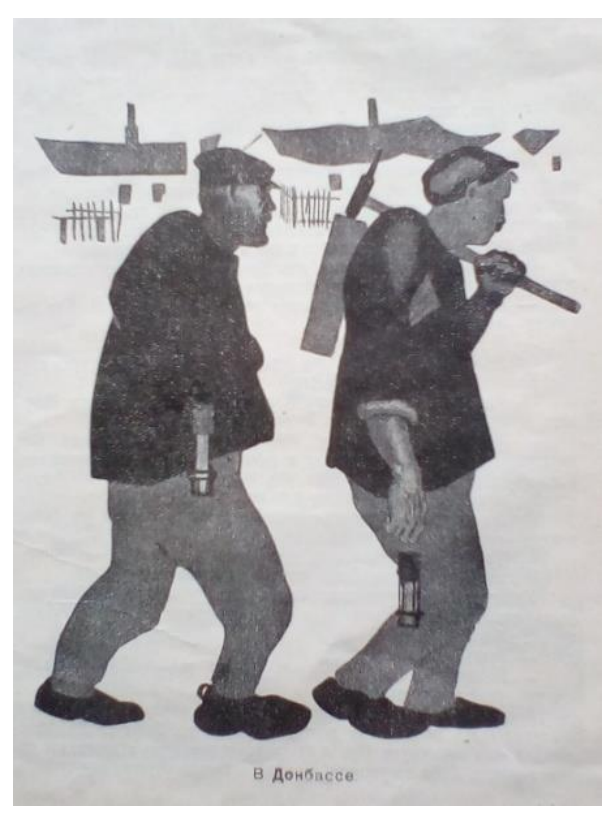

Рис. 5. В Донбассе

Fig. 5. In Donbass

«В своих рисунках он не смягчает по-прежнему избыточную зависимость шахтерской профессии от физических возможностей человека. Телесный фактор играет значительную роль в образно-пластической конструкции фигур» [Сысоев, 1989, с. 39].

«Дейнека принципиально отказывается от какой бы то ни было идеализации. Его коротконогие мезоморфические герои-современники подчеркнуто антиинтеллектуальны, прозаичны и отнюдь не окружены героической аурой» [Барабанов, 2004, с. 82].

«...его вещи, проникнутые пафосом индустриального созидания, показывали человека труда остро, жестко, без малейших прикрас» [Чегодаева, 2003, с. 45].

Подобный подход к трактовке образов обусловлен вниманием художника к передаче обобщенных профессиональных признаков, а не индивидуальных характеристик рабочих. Суровая повседневная жизнь шахты, связанная с физическими перегрузками (в условиях крайне низкого уровня механизации), с работой в опасных и дискомфортных условиях требовала людей здоровых, выносливых, устойчивых к стрессовым ситуациям, способных концентрироваться на своем деле. Для их изображения Дейнека вырабатывает лаконичный стиль графики, который позволяет ему наделять своих героев не просто очевидной мышечной силой, но и силой личностной.

В этом новом стиле выполнена Дейнекой обложка следующего номера журнала [Рогинская, 1926], ставшая прообразом огромной картины «Перед спуском в шахту», представленной художником на І выставке картин ОСТ (Общества станковистов) в 1925 г. (рис. 6).

Большие, четкие силуэты забойщиков, ожидающих своей очереди на спуск в шахту, сразу привлекают внимание к журнальной обложке (зоркий зритель разглядит также силуэты рабочих, либо уже зашедших в шахтную клеть, либо занимающих в ней последние оставшиеся места). У клети подъемника застыли в ожидании фактически те самые шахтеры, что недавно оживленно обсуждали новости в табельной. Они стоят у самого входа в шахту, будто отрешившись от всего, что не имеет отношения к ждущему их делу. По замечанию критика И.Л. Мацы, Дейнека избегает «оживляющей» сценки в виде спора, или веселого разговора, или еще какого-либо эпизода ожидания. «Дейнека дает эту будничную, изо дня в день повторяющуюся сцену, с одной стороны, именно как будничную, никаких особых переживаний у участников не вызывающую, с другой стороны, все же как значительную, без мелочей и без анекдотичности» [Маца, 1959, с. 16]. 


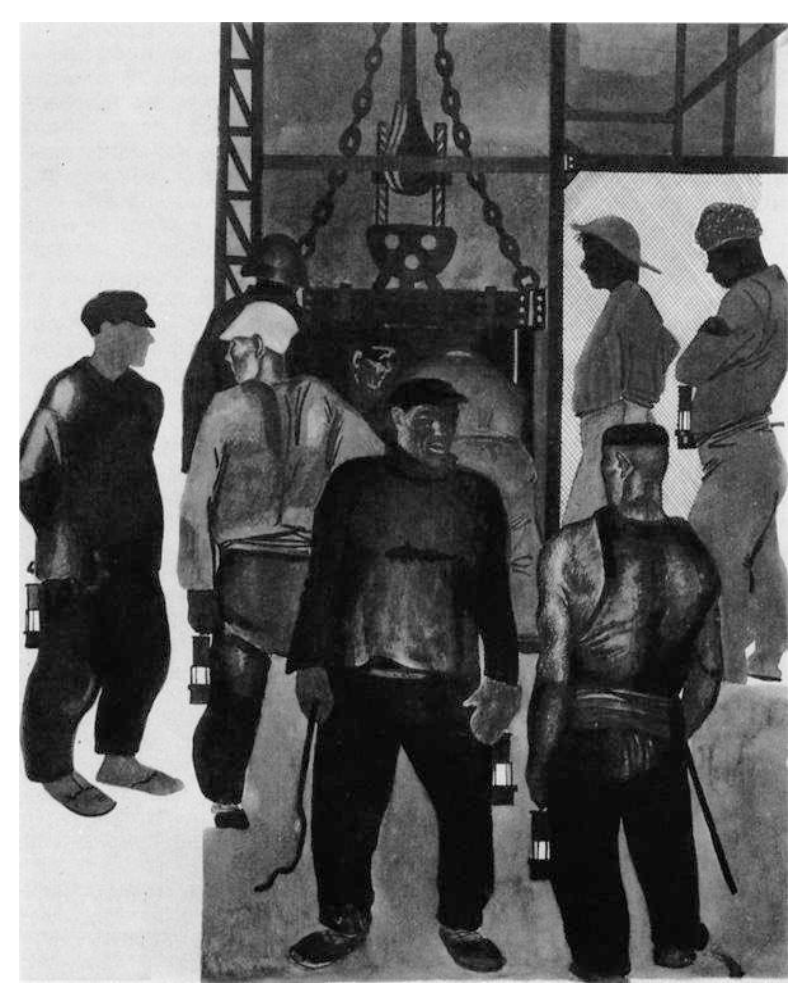

Рис. 6. Обложка журнала «У станка»

Fig. 6. Cover of the magazine «At the bench»

Искусствовед В.И. Костин, вспоминая выставку картин ОСТ, где Александр Дейнека представил две свои большие картины, отмечал сильное впечатление, произведенное ими на зрителей. Картины выглядели как увеличенные во много раз графические рисунки (в случае полотна «Перед спуском в шахту» так оно и было), но при этом «такого убедительного, жизненно верного изображения рабочих не мог достигнуть, по существу, ни один художник того времени» [Костин, 1976, с. 38]. Эти прямоугольные, мускулистые, широкоплечие фигуры будто созданы природой для преодоления сопротивления крепких угольных пластов. Тяжелый труд завершил их формирование, придав фигурам мощную кряжистость.

Дейнека воспел людей, осмысленность жизни которых придают результаты их труда. У них есть особый, свойственный только им талант - «талант рубать уголь» (Б.Л. Горбатов). Этот талант сформировал жизнеспособные и сильные личности, которые хорошо понятны читателю послереволюционной эпохи. «Шахтерская» графика Александра Дейнеки, в которой он впервые продемонстрировал свой независимый подход к изображению и трактовке рабочего человека, стала этапным явлением на пути создания нового стиля в искусстве - стиля, основанного на культе труда. И именно шахтер стал у художника главным героем этого нового культа.

Работая над обложкой, график стремился добиться максимального выразительного и смыслового эффекта, для чего применял различные художественные приемы. Например, намекая на вертикальный ствол шахты, он задает рисунку вертикальную композицию. Вертикаль выстраивается из элементов шахтного оборудования - клети подъемника, сетки ограждения - и плит бетонного пола. Выполненные в черно-серой гамме, они с определенностью очерчивают круг существования героев композиции - кадровых шахтеров, чья жизнь устойчиво, прочно связана с шахтой.

И только «одна из фигур, помещенная в светлом створе в левой части композиции, - по замечанию искусствоведа Т.В. Маловой, - оказывается вынесенной на периферию, "за скобки“ осуществляющегося действия» [Малова, 2008, с. 109]. Дейнека использует прием выведения персонажа за пределы цветовых плоскостей, помещая его на пустом бе- 
лом фоне. На наш взгляд, вполне допустима не только искусствоведческая трактовка подобного исключения персонажа из четко очерченного пространства существования остальных шахтеров. В социальном аспекте это исключение, возможно, указывает на неопределенность жизненной позиции персонажа.

Вопрос кадрового обеспечения шахт Донецкого бассейна долгое время оставался открытым. Нехватка квалифицированных рабочих кадров на шахтах характеризовала весь восстановительный период. Дело в том, что «к концу 1920 г. численность рабочих в угольном Донбассе сократилась почти вдвое по сравнению с 1913 г., особенно уменьшилось число забойщиков. В голодный 1921 г. происходило их дальнейшее сокращение. Общая довоенная численность была восстановлена здесь лишь в 1926-27 гг., а подземных рабочих - еще позже» [История социалистической..., 1976]. Но прилив рабочей силы не компенсировал ее качественного состава. Почти половина рабочих состояла из крестьян местных сел и деревень, которые часто рассматривали работу в шахте всего лишь как подсобное занятие, главным по-прежнему считая хлебопашество. Люди случайные, они перемещались с рудника на рудник в поисках лучших заработков, менее тяжелой работы и пр. Около трети рабочих удерживались на одном месте менее одного года, тогда как для практической подготовки горняка конкретной профессии в то время требовалось до двух лет. Перелом ситуации произойдет только во второй половине 1930-х гг.

В подборке иллюстраций А. Дейнеки к тексту В. Сарабьянова отсутствуют рисунки, посвященные труду шахтеров непосредственно под землей. Казалось бы, именно такой сюжет мог послужить смысловой точкой в «шахтерской» серии. Но и в размещенной на обложке следующего номера журнала [«У станка», 1924] графической работе Дейнека вновь прибегает к осознанной недосказанности. По собственному определению, он изображает шахтеров в «торжественно-напряженном» состоянии «ожидания труда», но не в процессе самого труда. График так и не завершает свою историю, оставляя читателю ощущение, что впереди будет ее обязательное продолжение.

В «шахтерской» графике Александра Дейнеки поиск новых форм художественной выразительности для идеологически значимых сюжетов сопряжен с очень пристальным личным вниманием автора ко всему происходящему у него на глазах. В отличие от историка, художнику доступен метод наблюдения, дающий ему возможность не только воочию видеть, но и запечатлевать события в момент протекания, процессы в динамике, а человека в характерных жизненных условиях и ситуациях. Зоркий наблюдатель, вовлеченный в процесс социальных преобразований, создания нового уклада, Дейнека взял на себя обязательство показывать то, «чем живет родина» так, «чтобы зритель сказал: я это видел, знаю». Его рисунки, наполненные деталями и приметами обыденной жизни шахтеров Донбасса почти 100-летней давности, способны и сегодня дать довольно целостное представление об этом особом мире, безгранично изменившемся, но в чем-то оставшимся точно таким же.

\section{Список литературы}

1. Барабанов Д.Е. 2004. Герой и героическое в советском искусстве 1920-1930-х годов: дис. ... кандидата искусствоведения. М., 215.

2. Газетный пласт: история прессы Донбасса. URL: http://novorossy.ru/historylessons/gazetnyy-plast-istoriya-pressy-donbassa (дата обращения: 04.03.2020).

3. Дейнека А.А. 1961. Из моей рабочей практики. М., Академия художеств СССР, 79.

4. История рабочих Донбасса. 1981. Т. 1. Киев, Наукова думка, 326.

5. Костин В.И. 1976. ОСТ (Общество станковистов). Л., Художник РСФСР, 159.

6. История социалистической экономики СССР. 1976. Т. 2: Переход к нэпу. Восстановление народного хозяйства ССCР. 1921-1925 гг. М., Наука, 479. URL: http://indbooks.in/mirror8.ru/?p=70044 (дата обращения: 04.03.2020). 
7. Ленин В.И. 1974. Речь на I Всероссийском учредительном съезде горнорабочих. Полное собрание сочинений. Т. 40. М., Политиздат, 292-298.

8. Малова Т.В. 2008. Поэтика художников ОСТа: дис. ... кандидата искусствоведения. M., 173.

9. Маца И.Л. 1959. А. Дейнека. М., Советский художник, 80.

10. Никифоров Б.М. 1937. А. Дейнека. М.-Л., Изогиз, 121.

11. Никольский В.Н. 2017. Шахтеры Донбасса в статистических обследованиях 1923 года. Журнал исторических, политологических и международных исследований. 1: 7-17.

12. Постановление СНК о Московских высших государственных художественнотехнических мастерских. URL: http://docs.historyrussia.org/ru/nodes/12791-18-dekabrya-postanovleniesnk-o-moskovskih-vysshih-gosudarstvennyh-hudozhestvenno-tehnicheskih-masterskih (дата обращения: 04.03.2020).

13. Промышленность СССР в 1925 году: Ежегодник ВСНХ. 1926. Ч. 2. М.-Л., 750.

14. Развитие советской экономики. 1940. М., Государственное социально-экономическое издательство, 665.

15. Рогинская Ф.С. 1926. Обзор живописного сезона. Красная новь. 7: 225-233.

16. Сапицкая И.К. 2009. Формирование жизненного цикла угольной промышленности Донбасса. Экономика и промышленность. 3: 45-52.

17. Сарабьянов В.Н. 1924. Наш Донбасс. У станка. 2: 16-17.

18. Сысоев В.П. 1989. Александр Дейнека. Т. 1. М.: Изобразительное искусство, 328.

19. У станка. 1924. 3.

20. Чегодаева М.А. 2003. Социалистический реализм: Мифы и реальность. М., Захаров, 214.

\section{References}

1. Barabanov D.E. 2004. Geroj i geroicheskoje v sovetskom iskusstve 1920-1930-h godov [Hero and heroic in Soviet art of the 1920s and 1930s]: Dis. ... candidata iskusstvovedenija. M., 215.

2. Gazetnyj plast: istorija pressy Donbassa [Newspaper formation: history of the press of Donbass]. URL: http://novorossy.ru/history-lessons/gazetnyy-plast-istoriya-pressy-donbassa (access: 04.03.2020).

3. Deineka A.A. 1961. Iz mojej rabochej praktiki [From my work practice]. M., Academija hudozhestv SSSR, 79.

4. Istorija rabochih Donbassa [History of the workers of Donbass]. 1981. Vol. 1. Kiev, Naukova Dumka, 326.

5. Kostin V.I. 1976. OST (Obshestvo stankovistov) [OST (society of easel artists)]. L., Hudozhnik RSFSR, 159.

6. Istorija socialisticheskoj jekonomiki SSSR [History of the socialist economy of the USSR]. 1976. Vol. 2: Perehod k njepu. Vosstanovlenije narodnogo hozjajstva SSSR. 1921-1925 [Transition to NEP. Restoration of the national economy of the USSR. 1921-1925]. M., Nauka, 479. URL: http://indbooks.in/mirror8.ru/?p=70044 (access: 04.03.2020).

7. Lenin V.I. 1974. Rech' na I Vserossijskom uchreditel'nom sjezde gornorabochih [Speech at the first all-Russian constituent Congress of miners]. Polnoje sobranije sochinenij. T. 40. M., Politizdat, 292-298.

8. Malova T.V. 2008. Pojetika hudozhnikov OSTa [Poetics of OST artists]: Dis. ... candidata iskusstvovedenija. M., 173.

9. Maca I.L. 1959. A. Dejneka [A. Deineka]. M., Sovetskij hudozhnik, 80.

10. Nikiforov B.M. 1937. A. Dejneka [A. Deineka]. M.-L., Izogiz, 121.

11. Nikolskij V.N. 2017. Shahtjory Donbassa v statisticheskih obsledovanijah 1923 goda [Miners of Donbass in statistical surveys of 1923]. Zhournal istoricheskih, politologicheskih i mezhdunarodnyh issledovanij. 1: S. 7-17.

12. Postanovlenie SNK o Moskovskih vysshih gosudarstvennyh hudozhestvenno-tehnicheskih masterskih [Resolution of the SNK on the Moscow higher state art and technical workshops]. URL: http://docs.historyrussia.org/ru/nodes/12791-18-dekabrya-postanovlenie-snk-o-moskovskih-vysshihgosudarstvennyh-hudozhestvenno-tehnicheskih-masterskih (access: 04.03.2020).

13. Promyshlennost' SSSR v 1925 godu: Jezhegodnik VSNH [Industry of the USSR in 1925: Yearbook of the Supreme economic Council]. 1926. Part 2. M.-L., 750. 
14. Razvitije sovetskoj jekonomiki [Development of the Soviet economy]. 1940. M., Gosudarstvennoje social'no-jekonomicheskoje izdatel'stvo, 665.

15. Roginskaja F.S. 1926. Obzor zhivopisnogo sezona [Overview of the scenic season]. Krasnaja Nov'. 7: S. 225-233.

16. Sapitskaja I.K. 2009. Formirovanie zhiznennogo cikla ugolnoy promishlennosti Donbassa [Formation of the life cycle of the Donbass coal industry]. Jeconomica i promyshlennost'. 3: S. 45-52.

17. Sarab'janov V.N. 1924. Nash Donbass [Our Donbass]. U stanka. 2: S. 16-17.

18. Sysoev V.P. 1989. Aleksandr Dejneka [Alexander Deineka]. T. 1. M., Izobrazitel'noje iskusstvo, 328.

19. U stanka [At the bench]. 1924. 3 .

20. Chegodaeva M.A. 2003. Socialisticheskij realizm: mify i real'nost' [Socialist realism: Myths and reality]. M., Zaharov, 214.

\section{Ссылка для цитирования статьи Link for article citation}

Максименко Е.П. 2020. Шахтерская тема в журнальной графике Александра Дейнеки середины 1920-х гг. (журнал «У станка»). Via in tempore. История. Политология, 47 (2): 338-349. DOI 10.18413/2687-0967-2020-47-2-338-349.

Maksimenko E.P. 2020. Miner's theme in Alexander Deineka's magazine graphics of the mid1920s (the magazine «At the bench»). Via in tempore. History and political science, 47 (2): 338-349 (in Russian). DOI 10.18413/2687-0967-2020-47-2-338-349. 